\title{
The Effects of Leadership, Motivation, and Organizational Culture Toward Employees and Lecturers' Performance in the University of Bina Darma Palembang
}

\author{
Sunda Ariana (Author) \\ Universitas Bina Darma \\ Palembang, Indonesia \\ Dina Mellita \\ Universitas Bina Darma \\ Palembang, Indonesia
}

Ade Kemala Jaya

Universitas Bina Darma

Palembang, Indonesia

\begin{abstract}
This study aims to investigate the effects of leadership, motivation, and organizational culture toward employees and lecturers' performance in the University of Bina Darma Palembang. The population of the study is all the employees and lecturers of the University of Bina Darma Palembang with the total of 80 respondents selected through simple random sampling from 267 employees and lecturers. Data is analyzed with multiple linear regression. The results indicate that leadership and motivation have significant effects on employees and lecturers' performance in the University of Bina Darma Palembang meanwhile organizational culture does not.
\end{abstract}

Keywords-Leadership; Motivation; Organizational Culture; Performance

\section{INTRODUCTION}

University of Bina Darma Palembang has a vision to become "An International Standard University Based on Information Technology in 2025." Thus, the university has a commitment to produce quality graduates to compete in global labor markets. In or-der to achieve this, it requires outstanding perfor-mances from its employees and lecturers. These performances are determined by several factors and need further investigation.

To begin with, proficient leadership can improve employees' performance (Lok \& Crawford, 2004). This is because competent leaders can show and di-rect their employees on what and how to do their jobs in the most effective and efficient methods. These leaders also can create an environment where employees feel respected and appreciated. This even-tually will lead to job satisfaction and excellent per-formance. Apart from leadership, work motivation also contributes to employees' performance. An organization that is capable of providing rewards that complement its employees' needs (e.g., monetary rewards, respect, achievement, and personal development) has a possibility to encourage its employees to produce better performance (Asim, 2013). Lastly, organizational culture has the ability to shape em-ployees' mindset and work practices. When these meet an organization's mission and vision, they will ameliorate employees' productivity and performance (Deal \& Kennedy, 1982; Peters and Waterman, 1982).

Based on the aforementioned explanation, this re-search aims to empirically investigate the effects of leadership, motivation, and organizational culture on employees and lecturers' performance in the Univer-sity of Bina Darma Palembang. It focuses on three research questions. First, does leadership affect em-ployees and lecturers' performance in the University of Bina Darma Palembang? Second, does motivation affect employees and lecturers' performance in the University of Bina Darma Palembang? Third, does organizational culture affect employees and lectur-ers' performance in the University of Bina Darma Palembang? The findings of this study can benefit researchers and practitioners. Specifically, this re-search will extend the current literature on the ef-fects of leadership, motivation, and organizational culture on employees' performance in the education industry. For the practitioners (e.g., decision makers of higher education institutions), the findings can help them to develop proper strategy to enhance their employees and lecturers' performance. 
Every tertiary education institution, in an effort to achieve its goals in producing distinguished human resources, needs to apply the principles of good governance. The quality of a university graduate is a major consideration for consumers (public) in today's competitive labor markets. If most of the graduates can secure jobs after study, the university is deemed exceptional and hence their brand image is positive. Vice versa, if the graduates are mostly unemployed after study, the university's survivability deterio-rates. Improving the quality of higher education is related to the performance of lecturers in the fields of education, research and publications, as well as community service. The failure and success of higher education institutions in performing their functions are determined by the quality of the teaching and non-educational staff working in them (i.e., human resources). According to Mangkuprawira (2007), human resources are substantial aspects for organiza-tional survival. If there are organizational goals that are fail to be achieved, the human resource management approach is considered a failure. The perfor-mance of employees and lecturers is crucial in the success of a university in achieving its vision and mission.

That performance of employees mentioned above is strongly influenced by their competence and job satisfaction (Sahlan, 2002; Brahmasari \& Supray-etno; 2008; Al Khalifah \& Ali, 2002; Haskas, 2013). Motivation is the willingness to offer more efforts to achieve organizational goals that is caused by the willingness to satisfy individual needs (Robbins, 1996). Apart from monetary rewards, there are other aspects that motivate work such as appreciation for achievement, working environment, and personal development (Sara, 2004; Whitley, 2002). According to McClelland \& Boyatzis (1982), there are three types of needs that each individual possesses, name-ly: the need for achievement (achievement motiva-tion), the need for power (power motivation), and the need for affiliation (affiliation motivation). High level of motivation will encourage employees to ful-fil their responsibility and accomplish their jobs. In regard with this, studies have discussed the influ-ences of leadership and motivation on employees' performance. Hussain \& Ali (2012), Harwiki (2013), and Koesmono (2014) found that leadership is significantly influential on performance. Also, Al Kha-lifah \& Ali (2002) evidenced that motivation affects employees' performance.

In addition to leadership and work motivation, organizational culture also contributes in shaping employees' mindset and work practices. Inheritance of exceptional organizational values and culture will stimulate employees' awareness and productivity. According to Robbins in Moehariono (2012), organi-zational culture is a system of shared meanings of primary values practiced and valued by organiza-tions, that serves to create a clear distinction be-tween one organization to another, creating a sense of identity for members of the organization, facilitat-ing the emergence of collective commitments to-wards the organization, enhancing the stability of social system, as well as creating meaningmaking and control mechanisms that guide shaping the attitudes and behaviour of the members of the organization.

The success of an organization depends on the ability of the leaders to optimize their human re-sources. Competent leaders understand the signifi-cance of employees and motivating them to accom-plish the goals and objectives of the organization. One study found that effective organizations require effective leadership and the negligence of it will af-fect the performance of the companies negatively (Fidler \& House, 1988). Further studies also con-cluded that the effectiveness of a group relied on the quality of leadership. In this case, effective leader-ship can facilitate the needs of employees and this will enhance performance (Fiedler \& House, 1988; Maritz, 1995; Ristow et al., 1999). Specifically, leadership style is considered as a combination of various characteristics, traits, and behaviours utilized by leaders to interact with their employees (MitongaMonga et al., 2012). Mitonga-Monga et al. (2012) al-so indicated that leadership is a pattern related to managerial behaviour designed to integrate organiza-tional and personal interests that is substantial in achieving certain goals. Harris et al. (2007) also for-mulated leadership style as a relationship used by an individual to encourage others to collaborate in achieving particular objectives.

Klein et al. (2013) using the theory of four leader-ship factors examined 2,662 employees working in 311 organizations. They found that organizational culture and performance are closely related to lead-ership style. On the other hand, Storey (2004) for-mulated leadership in several dimensions that can in-fluence, inspire, stimulate intellectually, as well as possess considerations personally. Storey's opinion is also supported by Hoy \& Miskel (2006). In their re-search, they concluded that leadership based on these four dimensions can positively influence em-ployees satisfaction and organizational performance.

In order to improve employees' willingness to achieve organizational goals, motivating them is nec-essary. Highly motivated employees always strive to improve their work performance and this will help organizations to reach optimum performance (Omol-lo, 2015). The results obtained from highly motivat-ed employees are high productivity as well as low employees absence and turnover.

Another factor that affects employees' perfor-mance is organizational culture. Organizational cul-ture consists of unwritten habits, behavior, and be-liefs that determine decision making, structure, and strength in an organization. Hofferberth \& Urich (2011) in their study argued that organizational culture determines the business processes and survival strategies of an organization that will assimilate or-ganizational success. By having a robust organiza-tional culture, employees will act based on their be-lief that the culture is conscientious and if they ac-complish their job properly according to the culture they will receive a reward.

Conceptually, organizational culture that is often implemented in studies is Schein's organizational cul-ture model (2004). The Schein model has three di-mensional variables. The first dimension is the di-mension of external adaptation (external adaptation task), the dimension of internal integration (internal adaptation task), and the dimensions of basic as-sumptions (basic underlying assumptions). In Schein's theory, the scope of the external dimensions of adaptation variables is mission, goals, basic means, success measurement, and reserve strategies. Second, the dimensions of internal 
description of Employees and Lecturers' Performance variables has an average value of 3.43 in the category of Good. This proves that employees and lecturers in the Uni-versity of Bina Darma Palembang have satisfactory performance. The results of the questionnaires demonstrate that in terms of quality, employees and lecturers are able to work thoroughly in carrying out the work provided and their competency is in accordance with the established quality standards. This condition is also supported by the employees' and lecturers' performance reports from the HRD stating that the level of service complaints below the mini-mum threshold. In short, the employees and lecturers in the University of Bina Darma Palembang have contributed high level of performance.

In addition to the findings, the respondents evi-dence to possess clear, focus, and creative minds. These qualities relate to the other results. First, the respondents have sufficient work competency as ev-idenced by moderate level of accuracy. Second, they are able to accomplish their jobs in accordance with the established quality standards. Specifically, focus minds can avoid error and creative talents can pro-mote growth and success. These measures enhance the employees and lecturers' performance which in the end support the University of Bina Darma Pa-lembang in achieving its vision and mission.

The findings further prove that the employees and lecturers strive to fulfil their responsibilities in the best possible manner. This occurs as they try to avoid accomplishing certain jobs twice. As a result, it im-proves effectivity and efficiency. The employees and lecturers are also highly independent shown by their commitment and capability to finish their jobs with or without partners. Lastly, although other aspects are favourable, the employees and lecturers are evi-denced to have low level of loyalty. Once better op-portunities arrive they are willing to leave the university.

Furthermore, based on the multiple linear regres-sion analysis, the equation model for this study is: $\mathrm{Y}=3,924+$ $0,318 \mathrm{X} 1+0,150 \mathrm{X} 2+0,239 \mathrm{X} 3$, where Y (Performance), X1 (Leadership), X2 (Motivation) and X3 (Organizational Culture). Based on the F-test, the calculated $\mathrm{F}$ value $=21.81$ with the value of $\mathrm{R}$-Squared $=0.452$. The calculated $\mathrm{F}$ value is greater than the $\mathrm{F}$ table value with a probability of 0,000 . This indicates that the multiple regression equation model is fit to be used in analyzing the influence of leadership, motivation, and organizational culture on the performance of employees and lecturers in the University of Bina Darma Palembang.

These results demonstrated that leadership, motivation, and organizational culture simultaneously af-fect the performance of employees and lecturers in the University of Bina Darma Palembang. R-Squared value of 0.452 showed $45.2 \%$ of the varia-tion of employee and lecturer performance variables in the University of Bina Darma Palembang is influ-enced by leadership, motivation, and organizational culture.

To test the effects of the independent variables partially on the dependent variable, t-test was con-ducted. The test compared t-count and t-table ( $t$-count can be seen in the Coefficients table). For the effects of leadership variable on the performance variable, the calculated t-value obtained was 3.394 with a coefficient value of 0.318 , and a significance value $(\mathrm{sig})=0.001<0.05$. This shows the leadership variable 
has a positive effect on the performance of employees and lecturers in the University of Bina Darma University Palembang. Coefficient value of 0.318 means for every $1 \%$ increase in leadership, performance will increase $31.8 \%$. These indicate good leadership can improve employees' performance. These findings concur with Syamsuddin (2006) and Brahmasari \& Suprayetno (2008).

The significant impact of leadership on perfor-mance is justifiable. DuBrin (2015) and Brahmasari \& Suprayetno (2008) all agreed that leadership is a process of influencing and inspiring people to ac-complish certain tasks based on instructions and or-ders to achieve common goals. This suggests that the better the leadership style the higher the employees' performance.

Then, the next t-test is for the effect of the Moti-vation variable on the performance of employees and lecturers variable. The $t$-count value is 2.165 , the co-efficient is 0.150 , and the significance value $(\mathrm{sig})=0.001<0.05$. This shows that the Motivation varia-ble influences the performance of employees and lec-turers in the University of Bina Darma Palembang. The coefficient value of 0.150 proving that for every $1 \%$ increase in work motivation, the employees and lecturers' performance will increase by $15 \%$. These evidence that motivation has a significant positive impact on performance. These findings are in line with previous studies (Sirajuddin 2008; Shahzadi et al., 2014).

Motivation is about giving employees the correct mixture of guidance, direction, resources, and re-wards so that they are inspired and keen to work in the way that any leaders aspire them to (Luthans, 2002). Highly motivated employees have their goals aligned with those of the organization and direct their efforts in that direction (Khan et al., 2010). Based on these, to promote success and achieve its vision and mission, the University of Bina Darma must take into consideration on how to motivate its employees and lecturers.

Lastly, the t-test aims to measure the effect of the organizational culture variable on the variable of em-ployees and lecturers' performance. The results show that the t-count value is 1.102 , the coefficient is -0.239 , and the significance value is $(\mathrm{sig})=0.070>0.05$. This indicates that the organizational culture has no significant effect on the employees and lec-turers' performance in the University of Bina Darma Palembang. These findings agree with the previous study of Arifin (2015) but contradict with Brahmasari and Suprayetno (2008).

In relation to the findings of Arifin (2015), the insignificant effect of organizational culture on em-ployees' performance occurs due to the ineffective-ness of the culture and the absence of strict applica-tion of the culture. Thus, in regard with the Universi-ty of Bina Darma, in order to grow its employees and lecturers' performance, its management and leader should focus more on formulating positive and impactful culture. Further, they also should enforce its employees and lecturers to apply the culture

\section{CONCLUSION}

This study proves that leadership, motivation, and organizational culture simultaneously affect employ-ees and lecturers' performance in the University of Bina Darma Palembang. Partially, leadership and motivation have significant impacts while organiza-tional culture has no significant effect on employees and lecturers' performance in the University of Bina Darma Palembang. For the university itself, these findings offers two suggestions. First, the University of Bina Darma Palembang should focus more on im-plementing competent leadership and improve work motivation for their employees and lecturers to en-hance their performance. Second, the university should construct relevant and impactful organiza-tional culture and enforce its employees and lecturers to implement it.

In general, this study contributes to and extend the current literature on the effects of leadership, motivation, and organizational culture on the per-formance of employees in the education industry. As the findings of this study are still inconclusive rela-tive to previous studies, especially the organizational culture, future studies should investigate such varia-ble further. This study also implements multiple regression analysis. Future studies should analyze more complex relationships among all the variables that af-fect performance (e.g., job satisfaction, leadership style, age, gender, religion) using SEM (Structural Equation Modelling).

\section{REFERENCES}

[1] Al Khalifa \& Ali, K. (2002). On The Relationship between Initial Motivation, Satisfaction and Per-formance in Joint Ventures. University of Bah-rain Amstrong.

[2] Arifin, M.H. (2015). The influence of competence, motivation, and organisational culture to high school teacher job satisfaction and performance. International Education Studies, 8(1), 38-45.

[3] Asim, M. (2013). Impact of motivation on employee performance with the effect of training: specific to education sector of Pakistan. International Journal of Scientific and Research Publications, 3, 1-9.

[4] Brahmasari, I. A., \& Suprayetno, A. (2008). Effect of Work Motivation, Leadership and Organiza-tional Culture Employee Satisfaction and its Impact on Corporate Performance (Case Study at PT. Pei Hai International wiratama Indone-sia). Journal of Management and Entrepreneur-ship, 10(2), 124-135.

[5] Deal, T. \& Kennedy, A. (1982). A Corporate Cul-ture. Reading, MA: Addison-Wesley.

[6] DuBrin, A.J. (2015). Leadership: Research Findings, Practice, and Skills. Nelson Education.

[7] Fiedler, F.E. and House, R.J. (1988). Leadership Theory and Research: A Report of Progress. In-ternational Review of Industrial and Organisational Psychology, 19(88), 73-91.

[8] Harris, A. (2007). Distributed leadership: conceptual confusion and empirical reticence. International Journal of Leadership in Education, 10(3), 1-11.

[9] Harwiki, W. (2013). The influence of servant leader-ship on organizational culture, organizational commitment, organizational citizenship behavior and employees' performance (study of outstand-ing coperatives in East Java Province, Indone-sia). Journal of Economics and Behavioral Stud-ies, 5(12), 876-885.

[10] Haskas, Y. (2013). Pengaruh Kompetensi Terhadap Motivasi, Prestasi, Penghargaan dan Kepuasan Kerja Dosen pada Sekolah Tinggi Ilmu Kesehatan Provinsi Sulawesi Selatan. Disertasi, Unpublished PPs-UMI Makassar, Indonesia.

[11] Hofferberth, D. \& Urich, J. (2011). The effect of cul-ture on performance. SPI Research.

[12] Hoy, K.W. \& Miskel, C. (2006). Educational Lead-ership and Reform. Greenwich: Information Age Publishing. 
in Migori County. International Journal of Human Resource Studies, 5(2), 87-103.

[25] Peters, T. \& Waterman, R. (1982). In Search of Ex-cellence. London: Harper and Row.

[26] Ristow, A., Amos, T. \& Staude, G. (1999). Trans-formational leadership and organisational effec-tiveness in the administration of cricket in South Africa. South African Journal of Business Man-agement, 30(1), 1 5 .

[27] Robbins, S. P. (1996). Organization Theory. Struc-ture, Design and Applications. Englewood Cliff-is: Prentice Hall International.

[28] Sahlan, A. (2002). Teori Motivasi. Dalam Pendeka-tan Psikologi Industri dan Organisasi. Jakarta: Studia Press.

[29] Sara, P. (2004). Learning and skills for sustainable development: developing a sustainability literate society. Forum for the Future.

[30] Schein, E. H. (2004). Organizational Culture and Leadership, Third Edition. Jossey-Bass.

[31] Shahzadi, I., Javed, A., Pirzada, S.S., Nasreen, S., \& Khanam, F. (2014). Impact of Employee Moti-vation on Employee Performance. European Journal of Business and Management, 6(23), 159-166.

[32] Sirajuddin (2008). Pengaruh Karakteristik Pribadi, Kompetensi, Sikap Kepemimpinan, dan Komu-nikasi Terhadap Kepuasan, Motivasi, dan Kiner-ja Karyawan BPR di Sulawesi Selatan. Disertasi Tidak Dipublikasikan. Unhas, Makassar.

[33] Storey, J. (2004). “Signs of change: 'damned rascals' and beyond.” In J. Storey (eds) Leadership in Organizations: Current Issues and Key Trends, London: Routledge.

[34] Sugiyono, T. (2004). Metode Penelitian Bisnis. Ban-dung: CV Alfabeta.

[35] Syamsuddin (2006). Analisis Pengaruh Karakteristik Individu Terhadap Perilaku Kepemimpinan, Kinerja Bawahan dan pertumbuhan usaha. Studi Kasus Industri Kecil Manufaktur di Sulawesi Se-latan. Disertasi Tidak Dipublikasikan. PPS Un-has, Makassar.

[36] Whitley, R. (2002). Competing Capitalisms: Institu-tions and Economies. Elgar: Cheltenham.

[24] Omollo, P.A. (2015). Effect of motivation on em-ployee performance of commercial banks in Kenya: A case study of Kenya Commercial Bank 